\title{
Rola ojca w kontekście hospicyjnego wsparcia terminalnie chorego dziecka i jego rodziny
}

Ojciec jest jedną z najważniejszych osób w życiu człowieka. Pomimo że ojcostwo przeżywa dzisiaj bardzo poważny kryzys, wciąż jest podstawową płaszczyzną, w oparciu o którą kształtują się postawy pozostałych członków rodziny, a zwłaszcza dzieci. Relacja pomiędzy ojcem i dziećmi konstytuuje bycie ojcem, a jednocześnie określa zadania, które przed nim stoją. Związane są one przede wszystkim z organizacją życia rodziny i realizacją funkcji rodzicielskiej. W rodzinie wydolnej w swoim funkcjonowaniu uskutecznienie tych zamierzeń przebiega bez większych zakłóceń i nie wymaga wsparcia ze strony państwa, szkoły czy organizacji pomocowych. Im niższy poziom wydolności opiekuńczo-wychowawczej rodziny, tym bardziej konieczne jest wsparcie zewnętrzne rodziny. Dzieje się tak nie tylko wtedy, gdy dochodzi do eskalacji czynników patogennych w rodzinie, ale również w przypadku, gdy rodzina staje się niewydolna z powodu czynników zewnętrznych, niezależnych od niej. Taka sytuacja ma miejsce w momencie pojawienia się choroby terminalnej ${ }^{1}$, zwłaszcza gdy dotyka ona dziecko. Więzi rodzinne zostają wtedy poddane mocnym przesileniom, które mogą spowodować zakłócenia w realizacji podstawowych zadań rodzicielskich. Mogą one także utrudnić wypełnianie zadań wynikających z bycia ojcem.

Choroba dziecka diametralnie zmienia sytuację rodziny, która musi zmierzyć się z nowymi, trudnymi zadaniami wynikającymi z zaistniałych okoliczności. Jak pokazuje doświadczenie, nie zawsze udaje się rodzinie je wypełnić. Opuszczenie rodziny przez męża lub żonę to $\mathrm{z}$ jednej strony ucieczka, a z drugiej wołanie o pomoc. Pojawia się więc wiele istotnych pytań. Trzeba bowiem zastanowić się, kto i w jaki sposób powinien udzielać pomocy, by przyniosła ona zamierzony skutek. Pomoc musi być adekwatna do potrzeb rodziny, co w praktyce polskiej opieki medycznej

${ }^{1}$ Por. K. de Walden-Gałuszko, Problemy psychiczne, duchowe i etyczne, [w:] Pielegniarstwo w opiece hospicyjnej, red. K. de Walden-Gałuszko, A. Kaptacz, Warszawa 2008, s. 195. 
oznacza dla dziecka pobyt w szpitalu, a dla rodziców życie pomiędzy domem a oddziałem szpitalnym.

Podkreślić należy, że w działaniach pomocowych następuje skupienie uwagi na dziecku i jego chorobie, wciąż natomiast brakuje zaplecza i narzędzi umożliwiających skuteczne wsparcie rodziny małego pacjenta. Jedną z nowych form wsparcia chorego dziecka i jego rodziny są hospicja dla dzieci, które często przyjmują formę opieki domowej. Wsparcie, jakiego te instytucje mogą udzielić, stwarza szansę na uzyskanie adekwatnej pomocy przez wszystkich członków rodziny. W zamierzeniach działalności hospicyjnej wsparcie ma zostać udzielone wszystkim, którzy go potrzebują, a więc także rodzicom, którzy dzięki niemu są w stanie dobrze wypełniać role opiekuńczo-wychowawcze. Dalsza analiza form wsparcia hospicyjnego będzie dotyczyć przede wszystkim ojców. Dla pełnego zobrazowania tej kwestii konieczne jest przytoczenie podstawowych prawd związanych z rolą ojca w domu.

\section{Rola ojca w życiu rodziny}

Obecność każdego z członków rodziny ma niebagatelne znaczenie dla pozostałych domowników, zarówno dzieci, jak i dorosłych. Wzajemny wpływ oparty jest na więzi społecznej łączącej poszczególne jednostki. Rola ojca polega na oddziaływaniu na dzieci i pozostałych członków rodziny. Jego podstawą są więzi społeczne, nabierające w życiu rodzinnym szczególnego charakteru.

\section{Więzi społeczne w systemie rodzinnym}

Każda więź społeczna posiada warstwę obiektywną, która wyraża się w zachowaniach wynikających ze wzajemnych związków. Jest ona w dużym stopniu niezależna od woli człowieka. Subiektywną warstwę stanowią natomiast zachowania spontaniczne, nacechowane dużym ładunkiem emocjonalnym i wynikające z osobistego zaangażowania się $\mathrm{w}$ relacje $\mathrm{w}$ danej grupie społecznej ${ }^{2}$.

W przypadku relacji zachodzących $w$ rodzinie można przyjąć, że posiadają one takie same podstawy, jak każda więź społeczna. Założenia obiektywne, związane z czynnikami prawnymi, społecznymi, gospodarczymi czy religijnymi, pozwalają daną grupę społeczną określić mianem rodziny bądź też powodują, że dana grupa społeczna nią nie jest. Rozpatrując pod tym kątem problematykę rodzinną, można dokonać zewnętrznego opisu rodziny. Nie sposób jednak dotrzeć do jej wnętrza, pełnego wspólnych celów, uczuć czy interakcji. Od proporcji pomiędzy czynnikami subiektywnymi i obiektywnymi zależy więc jakość więzi osobowych panujących w rodzinie.

Taki model rodziny jest zbieżny z ujęciem systemowym tej grupy społecznej. Cechą charakterystyczną systemowego modelu rodziny, obok silnych interakcji

${ }^{2}$ Por. J. Brągiel, S. Kawula, Więzi spoleczne w rodzinie, [w:] Pedagogika rodziny. Obszary i panorama problematyki, red. S. Kawula, J. Brągiel, A. W. Janke, Torun 2007, s. 115. 
pomiędzy jej członkami, jest węzeł sprzężenia zwrotnego, który może przyjmować negatywne bądź pozytywne zabarwienie ${ }^{3}$. Utrzymuje on funkcjonowanie systemu rodzinnego, opierając się na regułach panujących w domu. Reguły niekorzystne wychowawczo, a także wzmacniające je negatywne sprzężenie zwrotne prowadzą do powstawania więzi toksycznych. Z kolei przyjęcie zdrowych reguł i zasad prowadzi do utworzenia spójnego systemu rodzinnego. Mechanizm ten jest szczególnie istotny w kształtowaniu postaw wobec cierpienia. Pojawienie się choroby dziecka $\mathrm{z}$ reguły bardzo mocno narusza system rodzinny i jego funkcjonowanie:

Im bardziej ktoś, przystosowując się do konfrontacji z sytuacją długotrwałego stresu, wchodzi w określoną rolę, tym bardziej traci swoją własną tożsamość. Wraz z usztywnieniem się ról, system rodzinny staje się coraz bardziej zamknięty, rodzina zostaje uwięziona ${ }^{4}$.

Tak dzieje się w dysfunkcjonalnym systemie rodzinnym. By temu zapobiec, konieczna jest elastyczność, umiejętność zamiany ról i reorganizacji reguł życia wobec pojawiającego się stresu, a także zdolność do korzystania ze wsparcia zewnętrznego, gdy zachodzi taka konieczność. System rodzinny nie może się jednak stać w pełni funkcjonalny, gdy brakuje w nim osób stanowiących o jego istocie. Taka osobą jest ojciec i mąż, od którego oczekuje się funkcjonowania nie tylko na poziomie obiektywnym, ale także kreowania więzi rodzinnych o subiektywnym charakterze.

\section{Zadania ojca wobec rodziny}

Analiza roli ojca w życiu rodzinnym wykracza poza zakres niniejszego artykułu, gdyż winna ona objąć liczne aspekty związane z psychopedagogicznym czy też socjologicznym ujęciem tego zagadnienia. Dla potrzeb dalszych wywodów konieczne jest jednak przedstawienie zarysu tego problemu. Analizując pozycję ojca w realizacji procesu wychowawczego, należy skupić się nie tylko na zadaniach, jakie wyznacza mu przyjęta rola rodzicielska czy małżeńska, ale przede wszystkim na jakości ich wypełniania.

Z perspektywy wychowawczej więzi łączące ojca z dziećmi są bardzo istotne, gdyż wpływają na kształt postaw dzieci. Wpływ ten może mieć charakter bezpośredni, gdy ojciec bierze udział w czynnościach opiekuńczo-wychowawczych nad dzieckiem bądź pośredni, gdy zaspokajając potrzeby matki, ojciec przyczynia się do podniesienia jakości wychowania ${ }^{5}$. Bezpośredni kontakt ojca z dziećmi ma ogromny wpływ na rozwój dziecka, a zwłaszcza na jego sferę emocjonalną. Podkreślić jednak należy, iż kontakt ojca z dzieckiem pozostaje w ścisłej zależności od wzajemnych relacji rodziców:

${ }^{3}$ Por. J. Zamorski, Życie rodzinne jako program wychowania do partnerstwa, [w:] Partnerstwo w rodzinie. Istota i uwarunkowania relacji między rodzicami i dziećmi, red. J. Truskolaska, Lublin 2009, s. 82.

${ }^{4}$ Tamże, s. 83 .

${ }^{5}$ Por. J. Brągiel, S. Kawula, Więzi społeczne..., s. 121. 
Bez miłości małżeńskiej miłość rodzicielska będzie zawsze w jakiś sposób niepełna. Dziecko potrzebuje bowiem dla swojego wzrostu nie tylko indywidualnej miłości ojca i matki, ale świadectwa ich wzajemnej miłości ${ }^{6}$.

Przykład wzajemnej miłości rodziców jest potwierdzeniem prawdziwości ich przekazu kierowanego do dzieci. Opierając się na powyższych założeniach, można stwierdzić, że najistotniejszym zadaniem ojca jest zbudowanie domu, który obejmuje przestrzeń fizyczną i zabezpieczenie materialne, ale także właściwy klimat, pełen wzajemnej troski i życzliwości ${ }^{7}$ W tej przestrzeni można wyróżnić następujące zadania ojca ${ }^{8}$ :

- Budowanie poczucia bezpieczeństwa całej rodziny. Gdy ojciec dobrze wypełnia swoje funkcje, to jego obecność buduje poczucie stabilizacji i bezpieczeństwa w rodzinie. Z kolei słaby związek emocjonalny dziecka z ojcem jest uznawany za główną przyczynę nasilania się lęku u dzieci ${ }^{9}$. Skutkiem dłuższej nieobecności ojca w domu mogą być agresja i trudności w kontaktach społecznych ${ }^{10}$.

- Dbałość o wzajemny szacunek, porozumienie, przebaczenie i pojednanie. Bycie ojcem w perspektywie religijnej oznacza wejście w akt stworzenia, którego dokonał Bóg. To daje ojcu przywilej pielęgnowania w swoich dzieciach życia, miłości i szczęścia, na wzór Stwórcy, który troszczy się o dobro swoich dzieci. W czasach kryzysu ojca należy „przywrócić ojcostwu jego godność i przypomnieć, jak wielką wagę ma ta misja" ". Staje się ona możliwa do zrealizowania jedynie przy czynnym współudziale obojga małżonków, którzy szanując się nawzajem i wybaczając sobie, mają wpływ na kształtowanie postaw dzieci.

- Wspólne wypełnianie obowiązków. Coraz częściej podział obowiązków związanych z funkcjonowaniem domu rozumiany jest jako przesunięcie na ojca zadań, które w tradycyjnym modelu rodziny kojarzone są z matką. Rolą ojca nie jest jednak bierne przejęcie tych obowiązków, gdyż nie chodzi tutaj o bezrefleksyjne podporządkowanie się współczesnym trendom, ale chęć partycypowania w nich. Zwrot w stronę partnerstwa nie oznacza więc zagubienia właściwych sobie ról ${ }^{12}$. Ważną umiejętnością, jaką powinni wypracować małżonkowie, jest wymiana obowiązków, zwłaszcza w sytuacjach nadzwyczajnych.

- Budowanie postawy wdzięczności. Wdzięczność małżonków winna wypływać ze świadomości, „iż wszystko, czym wzajemnie się obdarzają, jest łaską”13. Taka

${ }^{6}$ J. Augustyn, Ojcostwo. Aspekty pedagogiczne i duchowe, Kraków 2009, s. 197.

${ }^{7}$ Por. tamże, s. 198.

${ }^{8}$ Por. tamże, s. $198-204$.

${ }^{9}$ Por. J. Brągiel, S. Kawula, Więzi społeczne..., s. 121.

${ }^{10}$ Por. M. Przetacznik-Gierowska, Z. Włodarski, Psychologia wychowawcza, t. 2, Warszawa 2002, s. 143.

${ }^{11}$ C. Risé, Sztuka ojcostwa, Poznań 2006, s. 20.

${ }^{12}$ Por. A. Regulska, Etyczno-pedagogiczny wymiar relacji partnerskich w rodzinie, [w:] Partnerstwo w rodzinie..., s. 139.

${ }^{13}$ J. Augustyn, Ojcostwo..., s. 203. 
postawa jest przeciwieństwem postawy roszczeniowej, będącej przejawem napięć i pretensji. Ojciec, który jest wdzięczny za otrzymywane dobra, uczy umiaru w zdobywaniu środków materialnych oraz szacunku do tego, co rodzina posiada. Dzięki temu ma ona szansę uniknąć postawy niewdzięczności ze strony dzieci, a jeśli korzysta ze świadczeń pomocowych, to jest w stanie uchronić się przed postawą wyuczonej bezradności.

Analizując rolę ojca w życiu rodziny, zwrócono uwagę na kilka wybranych aspektów tego zagadnienia, co pozwoliło dostrzec jego ważność. Skonfrontowanie tych zasad ze zmienną niezależną, jaką jest choroba dziecka, może ukazać trudności w realizacji funkcji rodzicielskich.

\section{Zaburzenia w realizacji roli ojca związane z chorobą dziecka}

Rodzicielstwo doświadczane jako dar umożliwia ,przeżycie wszystkich danych przez naturę wymiarów satysfakcji płynących z uczestnictwa we wspólnocie małżeńskiej”14. Dziecko, którego narodziny są naturalną konsekwencją miłości małżeńskiej, jest źródłem radości rodziców. Wielkim dramatem dla rodziców jest uzmysłowienie sobie faktu, że nowo narodzone dziecko jest ciężko chore lub że u zdrowego dziecka pojawiły się poważne zaburzenia zdrowotne. Wstrząs wywołany cierpieniem dziecka i jego leczeniem powoduje poważne zmiany w strukturze rodzinnej:

Chore dziecko staje się osobą centralną, skupiającą na sobie zainteresowanie, uwagę i uczucia przede wszystkim rodziców, ale często także i innych członków rodziny ${ }^{15}$.

Cierpienie dziecka może ogarnąć członków rodziny do tego stopnia, że w pediatrii coraz częściej mówi się o „,pacjencie zbiorowym”"16 , stosując do niego zasadę zaczerpniętą ze środowiska pielęgniarskiego: „Pacjent cierpi z powodu objawów, ale to rodzina doświadcza choroby" ${ }^{\prime 17}$. Wobec choroby dziecka nie sposób pozostać obojętnym, zwłaszcza gdy mały pacjent to członek grupy społecznej, którą tworzy rodzina.

Modyfikacja funkcjonowania rodziny i sposobów realizacji roli ojca

Wielowymiarowość cierpienia i jego odniesienia społeczne stały się podstawą do utworzenia koncepcji „cierpienia totalnego, wszechogarniającego"18. Obejmuje ono środowisko dziecka i w sposób szczególny dotyka rodziców. Trzeba zwrócić

${ }^{14}$ S. Głaz, K. Grzeszek, J. Wiśniewska, Rodzina. Biologiczne i psychologiczne podstawy jej funkcjonowania, Kraków 1996, s. 86.

${ }^{15}$ E. Wielgosz, Dzieci przewlekle chore, [w:] Dziecko niepetnosprawne w rodzinie, red. I. Obuchowska, Warszawa 1991, s. 434.

${ }^{16}$ Por. tamże, s. 444.

${ }^{17}$ R. Becker, Wymiar psychospoleczny, [w:] Opieka paliatywna, red. S. Kinghorn, S. Gaines, K. de Walden-Gałuszko, A. Gaworska-Krzemińska, Wrocław 2012, s. 88.

${ }^{18}$ Por. J. Binnebesel, Opieka nad dziećmi i młodzieża z choroba nowotworowa - w oczach pacjenta, Toruń 2003, s. 16-21. 
uwagę na osobę ojca chorego dziecka, i to właśnie pod tym kątem warto prześledzić niektóre obszary zaburzeń systemu rodzinnego ${ }^{19}$ :

- Zmiany zachodzące w relacji między małżonkami. Duża część czynności opiekuńczych nad chorym dzieckiem spada na matkę, co spotyka się z akceptacją większości ojców. Brak współpracy między rodzicami bądź akceptacji chorego dziecka może prowadzić do pojawienia się napięcia pomiędzy małżonkami, a w efekcie do rozluźnienia więzów. Ojcowie niejednokrotnie czują się zaniedbani przez żony i mają trudność w zaakceptowaniu faktu, że zainteresowanie nimi nie jest już tak duże, jak przed pojawieniem się choroby dziecka.

- Zmiany zachodzące w relacjach ze zdrowymi dziećmi. W sytuacji, gdy ojciec akceptuje chore dziecko i to właśnie jemu poświęca całą swoją uwagę, istnieje zagrożenie, że zdrowe rodzeństwo stanie się „niewidzialne”, ponieważ rodzice na pierwszym miejscu postawią potrzeby chorego dziecka i będą zaniedbywać jego rodzeństwo ${ }^{20}$. Z kolei, gdy brakuje podstawowej akceptacji chorego dziecka, może pojawić się tendencja, by stawiać zdrowemu rodzeństwu zbyt wygórowane wymagania.

- Modyfikacja życia zawodowego rodziców. Najczęstszym rozwiązaniem w tej kwestii jest przerwanie pracy zawodowej przez matkę. W tym czasie ojcowie, nie chcąc, by standard życia rodziny się obniżył, podejmują lepiej płatną bądź dodatkową pracę. Często rzutuje to na ich samopoczucie. Z powodu zwiększonej liczby obowiązków bywają przemęczeni. Zdarza się również, że mniej czasu spędzają z rodziną. Niekiedy praca może stać się pretekstem do ucieczki z domu czy szpitala.

- Przekształcenie życia towarzysko-kulturalnego. Choroba dziecka monopolizuje uwagę rodziców, zabiera ich czas i sprawia, że nie dysponują nim oni w sposób dowolny. Pobyty w szpitalu, stres związany z chorobą i konieczność codziennej opieki nad dzieckiem sprawiają, że opiekunom może zabraknąć sił i motywacji, by dbać o własny rozwój kulturalny czy o kontakty towarzyskie. W takiej sytuacji ojcowie korzystają częściej z internetu, telewizji czy prasy. W niektórych przypadkach świat mass mediów może stać się przestrzenią, która pozwala chwilowo zapomnieć o kłopotach, przynosi odprężenie, a także może stać się źródłem wiedzy na temat choroby. Internet jest również szansą na komunikację z rodzicami innych chorych dzieci. Trzeba jednak pamiętać o zagrożeniach dla rodziny, które mogą pojawić się w związku z destrukcyjnym oddziaływaniem mediów.

Choroba terminalna dziecka powoduje również zmiany w realizacji podstawowych funkcji rodziny: rodzicielskiej, seksualnej, opiekuńczo-wychowawczej, materialno-ekonomicznej czy socjalizacyjnej ${ }^{21}$. Warto zwrócić uwagę na poszczególne

${ }^{19}$ Por. A. Twardowski, Sytuacja rodzin dzieci niepetnosprawnych, [w:] Dziecko niepetnosprawne..., s. 47.

${ }^{20}$ Por. J. Binnebesel, Psychopedagogiczna opieka nad rodzeństwem dziecka ,, hospicyjnego”, [w:] Chore dziecko - chora rodzina. Materiaty konferencyjne, Gdańsk 2010, s. 6-9.

${ }^{21}$ Por. H. Budzeń, Wptyw środowiska rodzinnego na wychowanie dzieci i młodzieży, [w:] Prawne, administracyjne i etyczne aspekty wychowania w rodzinie, red. S. Bębas, E. Jasiuk, t. 1, Radom 2011, s. 186. 
funkcje, analizując je pod kątem roli, jaką odgrywa w nich ojciec. Podkreślono już, że cierpienie totalne ogranicza najczęściej możliwości finansowe rodziny, na co wpływa konieczność ciągłej opieki jednego z rodziców nad dzieckiem. Potrzeba zapewnienia dziecku optymalnych warunków opieki znacznie zwiększa wydatki rodziny. Dysonans, jaki się tworzy w takiej sytuacji, powoduje napięcia, z którymi muszą zmierzyć się rodzice, a zwłaszcza ojciec, gdyż najczęściej to na nim spoczywa obowiązek, by zapewnić rodzinie odpowiednie warunki materialno-ekonomiczne. Warto podkreślić, że zaspokojenie tych potrzeb jest ściśle związane z budowaniem poczucia bezpieczeństwa, które jest niezwykle ważne, jeśli chodzi o skuteczność leczenia ${ }^{22}$. Występująca dość często niemożność samodzielnego budowania przez ojca poczucia bezpieczeństwa w domu wywołuje frustracje, które potęgują napięcie w rodzinie. Jeśli w rodzinie przez dłuższy czas zaniechano realizowania zadań psychohigienicznych, u jej członków mogą pojawić się zaburzenia emocjonalne, skutecznie utrudniające codzienne funkcjonowanie. Jednym ze skutków tych napięć jest agresja, która zaburza kontakty społeczne.

Funkcje rodzicielska (prokreacyjna) i seksualna, ze swej natury winny być rozpatrywane razem, gdyż wyrażają osobę, będącą jednym bytem cielesno-duchowym. Kiedy dziecko jest przewlekle chore, może pojawić się trudność w praktycznym zachowaniu jedności między mężem i żoną. Często pojawia się lęk przed posiadaniem kolejnych dzieci $^{23}$, wynikający nie tyle z postawy egoistycznej, ile z poczucia odpowiedzialności za swoje potomstwo. Takie obawy pojawiają się zwłaszcza w sytuacji, gdy chore dziecko jest pierworodne i obciążone schorzeniem genetycznym. Ale nawet wtedy, gdy rodzice wiedzą, że dziecko nie ma takiego obciążenia, również mogą przeżywać rozdarcie pomiędzy pragnieniem posiadania następnego dziecka a lękiem, że urodzi się ono chore. Konsekwencje tego napięcia wpływają na relacje małżonków: „Konflikt taki rzutuje na stosunki między małżonkami i na atmosferę życia rodzinnego"24. W przypadku ojca, w związku z właściwym dla mężczyzny przeżywaniem seksualności, mogą pojawić się trudności w zachowaniu wierności małżeńskiej.

Funkcja opiekuńcza i wychowawcza w rodzinie należy do podstawowej przestrzeni aktywności realizowanych w środowisku rodzinnym. Obejmuje ona działalność stymulującą, asekuracyjną, kompensacyjną oraz działania ratownicze. Większość z tych zadań spoczywa na matce. Potrzebuje ona jednak wsparcia ze strony pozostałych członków rodziny. Działania opiekuńczo-wychowawcze, w które może włączyć się ojciec dziecka, są dla niego dużym wyzwaniem. By odciążyć żonę, mąż musi posiadać dużą wiedzę dotyczącą opieki nad chorym dzieckiem. Musi też przełamać

${ }^{22}$ Por. P. Krakowiak, E. Starkel, Socjalne potrzeby przewlekle chorych i ich rodzin, [w:] Przewlekle chory w domu. Poradnik dla rodzin i opiekunów, red. P. Krakowiak, D. Krzyżanowski, A. Modlińska, Gdańsk 2010, s. 288.

${ }^{23}$ Por. A. Twardowski, Sytuacja rodzin ..., s. 49.

${ }^{24}$ Tamże. 
w sobie naturalny lęk przed wyrządzeniem dziecku krzywdy. Wtedy łatwiej jest mu zbliżyć się do niego na poziomie emocjonalnym.

Istotą funkcji socjalizacyjnej jest przygotowanie dziecka do pełnienia przyszłych ról społecznych oraz wprowadzenie go w świat wartości ${ }^{25}$. W przypadku choroby terminalnej perspektywy społecznego rozwoju dziecka są zazwyczaj mocno ograniczone. Niemniej jednak potencjał społeczny ukryty w dziecku winien być w sposób optymalny zaktualizowany. Ma to miejsce wówczas, gdy rodzice pokonują własne opory przed ujawnieniem prawdy o chorobie dziecka w środowisku, którym żyją. Spacer ojca z chorym dzieckiem, jeśli pozwala na to stan fizyczny dziecka, jest wyraźnym komunikatem skierowanym do otoczenia, potwierdzającym akceptację swojego dziecka. Jej brak odbija się na jakości wysiłków zmierzających do przekazania dziecku podstawowych wartości, niezbędnych dla jego duchowego rozwoju i prowadzić może do zaniechania dalszych działań w tym względzie.

Profil stresu u ojców chorych dzieci

Poddając analizie zaburzenia w pełnieniu przez ojca swej roli, trzeba zwrócić uwagę na kluczowe dla tych rozważań pojęcie stresu. Stres pojawia się w kontekście prawie każdego zaburzenia emocjonalnego. Jest on przyczyną sprawczą wielu sytuacji i wynikiem „dynamicznej relacji pomiędzy człowiekiem a otoczeniem, która może być oceniana przez jednostkę albo jako wymagająca określonego wysiłku adaptacyjnego, albo przekraczająca możliwości jej sprostania"26. Choroba terminalna jest często niezwykle trudna do zaakceptowania przez członków rodziny, stąd stres jest spotęgowany.

Reakcja stresowa może obejmować zaburzenia występujące w sferze biologicznej, psychologicznej i behawioralnej ${ }^{27}$. Wszystkie one wynikają z traktowania sytuacji stresującej jako krzywdy bądź zagrożenia. Gdy stres zostaje potraktowany jako wyzwanie, łatwiej wypracować styl radzenia sobie z nim. W przypadku choroby dziecka rodzina staje przed koniecznością wypracowania własnej strategii adaptacyjnej, która nieraz zawiera elementy destrukcyjne. Rozpatrując rolę ojca w kontekście choroby dziecka, można stwierdzić, że adaptacja do sytuacji stresowej może wiązać się z próbą zmiany niekorzystnych zdarzeń, np. poprzez ucieczkę od trudnej sytuacji bądź też przez psychiczne przygotowanie się do trudnych momentów. Zdarza się również, że próba osłabienia wpływu stresu dokonuje się poprzez zaprzeczanie zaistniałym trudnościom, intelektualizację problemów czy też emocjonalne odcięcie się od trudnej sytuacji ${ }^{28}$.

${ }^{25}$ Tamże, s. 51.

${ }^{26}$ B. Ziółkowska, Dziecko chore $w$ domu, w szkole i u lekarza. Jak wspomagać rozwój dzieci przewlekle chorych, Gdańsk 2010, s. 74.

${ }^{27}$ Por. tamże.

${ }^{28}$ Por. tamże, s. 76-77. 
Rozważania teoretyczne na temat stresu ojców chorych dzieci zostają stopniowo uzupełniane przez badania empiryczne tego zjawiska ${ }^{29}$. Dzięki temu pojawia się szansa na lepsze zrozumienie i opisanie badanych kwestii. Jednak trudności pojawiające się podczas badań powodują, że proces ten przebiega powoli. Można już jednak dostrzec wyraźne różnice w sposobie przeżywania stresu przez matki i ojców chorych dzieci. Opierając się na wynikach badań, można stwierdzić, że poziom stresu związanego z zaburzeniami rozwoju dziecka jest niższy u matek niż u ojców, co prawdopodobnie wiąże się z podziałem ról w rodzinie i częstszą obecnością matek przy chorych dzieciach. Mężczyźni są mniej depresyjni i mają wyższą samoocenę. Są z kolei mniej wrażliwi na chwilowe poprawy kondycji dziecka, a ich stres związany jest z niepewną przyszłością dziecka. Ojcowie są bardziej wrażliwi na tzw. kłopotliwe zachowania dzieci, traktując je jako osobiste niepowodzenie wychowawcze ${ }^{30}$.

Jeszcze inaczej przedstawia się porównanie psychologicznego profilu stresu u ojców dzieci zdrowych i chorych. W świetle badań różni się on w zaledwie trzech na piętnaście skal Kwestionariusza Stresu i Zasobów J. Horloyda. Profil stresu ojców chorych dzieci specyfikuje się w następujących obszarach ${ }^{31}$ :

- negatywne postawy wobec dziecka - wrażliwość ojców w tym obszarze jest większa i oznacza to, że ojcowie chorych dzieci są bardziej wrażliwi na przejawy wrogości wobec chorego dziecka, natomiast w porównaniu z matkami chorych dzieci ich stres jest mniejszy,

- poczucie nadodpowiedzialności i samopoświęcenia - poczucie przeciążenia ojców chorych dzieci jest wyraźnie większe niż u ojców zdrowych dzieci,

- ograniczone możliwości rodziny - opieka nad chorym dzieckiem ogranicza możliwości rodziny, a im bardziej absorbująca jest choroba dziecka, tym to ograniczenie jest większe.

Na podstawie powyższych analiz można przyjąć, że choroba dziecka jest zmienną, która w bardzo istotny sposób wpływa na realizację funkcji i zadań, jakie są związane z życiem rodzinnym. Spowodowane chorobą trudności w ogromnym stopniu wpływają na rodziców, utrudniając im pełnienie ról rodzicielskich. Rodzina w stanie cierpienia wszechogarniającego potrzebuje więc wsparcia z zewnątrz. Winno ono objąć także ojców, których aktywna obecność w domu ma stanowić wsparcie dla pozostałych członków rodziny.

\footnotetext{
${ }^{29}$ Przegląd wyników badań na temat stresu związanego z chorobą dziecka, przeżywanym zależnie od roli rodzicielskiej prezentuje praca: E. Pisula, Rodzice i rodzeństwo dzieci z zaburzeniami rozwoju, Warszawa 2007. Badania na temat wsparcia udzielanego przez hospicjum domowe rodzinie z dzieckiem terminalnie chorym przeprowadziła E. Bartoszewska: por. E. Bartoszewska, Formy pomocy dziecku nieuleczalnie choremu i jego rodzinie, Kraków 2005. Autorka nie specyfikuje wyników badań pod względem ról pełnionych w rodzinie. Wciąż dostrzega się niedosyt badań empirycznych dotyczących wsparcia hospicyjnego rodziny w stanie choroby.

${ }^{30}$ Por. E. Pisula, Rodzice i rodzeństwo..., s. 50-51.

${ }^{31}$ Por. tamże, s. 71-74.
} 


\section{Wsparcie ojca chorego dziecka realizowane przez zespół hospicyjny}

Ogrom trudności, jaki wiąże się z chorobą dziecka, nie musi oznaczać, że życie rodzinne legnie w gruzach:

choroba nie może zupełnie zniszczyć domowników, nie powinna też uniemożliwiać członkom rodziny funkcjonowania w społeczeństwie ${ }^{32}$.

Ciężar cierpienia staje się łatwiejszy do uniesienia, gdy okazuje się, że rodzina może otrzymać wsparcie adekwatne do swoich potrzeb. Jedną z form tego wsparcia, stosunkowo od niedawna obecną na polskim rynku pomocowym, jest hospicjum dla dzieci ${ }^{33}$. Najczęściej przybiera ono formę opieki domowej, czyli takiej, w której dziecko przebywa w swoim domu, natomiast wsparcie medyczne i niemedyczne udzielane jest przez zespół odwiedzający rodzinę. Atmosfera domu rodzinnego, będącego naturalnym środowiskiem dziecka, stanowi ważny czynnik sprzyjający właściwej opiece nad nim ${ }^{34}$.

\section{Teoretyczne podstawy wsparcia hospicyjnego}

Oddziaływanie zespołu hospicyjnego opiera się na założeniu systemowego modelu rodziny, w którym wzajemne relacje stanowią podstawową płaszczyznę funkcjonowania. Adekwatna do tego modelu rodziny wydaje się pomoc o zespołowym i holistycznym charakterze ${ }^{35}$. $\mathrm{Z}$ założenia jest ona ukierunkowana przede wszystkim na chore dziecko, ale hospicjum jest jednocześnie gotowe świadczyć pomoc całej rodzinie chorego, zarówno rodzicom i zdrowemu rodzeństwu, jak i innym osobom dotkniętym przez cierpienie małego pacjenta. Staje się to możliwe dzięki oddziaływaniu zespołu o charakterze interdyscyplinarnym, czyli łączącym w sobie odpowiednio przygotowanych przedstawicieli różnych dziedzin wiedzy i obszarów życia społecznego. Personalistyczne ukierunkowanie tego modelu zakłada właściwe rozumienie godności osoby chorej, potrzeb jej rodziny oraz przekonanie o możliwości udzielenia skutecznego wsparcia społecznego. Dzięki temu hospicjum jest w stanie zapewnić ciągłą, odpowiednią opiekę nad chorym, a członkowie zespołu hospicyjnego mogą postępować zgodnie z etosem, który zakłada nie tylko świadczenie pomocy, ale przede wszystkim obecność w domu dziecka.

${ }^{32}$ R. Becker, Wymiar psychospoteczny, s. 88.

${ }^{33}$ O genezie ruchu hospicyjnego dla dzieci: J. Łuczak, Geneza działalności Warszawskiego Hospicjum dla Dzieci na tle ruchu hospicyjnego w Polsce i Europie, „Opieka Paliatywna Nad Dziećmi” $12: 2004$, s. 8-16.

${ }^{34}$ Por. T. Dangel, Opieka paliatywna nad dziećmi i młodzieża, [w:] Podstawy opieki paliatywnej, red. K. de Walden-Gałuszko, Warszawa 2006, s. 264.

${ }^{35}$ Por. P. Krakowiak, A. Paczkowska, E. Starkel, Praca socjalna w stużbie terminalnie chorym i ich bliskim w opiece paliatywno-hospicyjnej, [w:] Pozamedyczne aspekty..., s. 13-18. 
Ta obecność może posiadać bardzo twórczy charakter, który pomaga całej rodzinie, jak i poszczególnym jej członkom zmierzyć się z obecnym w ich domu cierpieniem. W świetle dokonanych analiz wyraźnie widać, że zadanie to jest bardzo trudne do zrealizowania, ale podkreślić należy, że doświadczenie pracy hospicyjnej znajduje potwierdzenie jego uskutecznienia. Mówiąc o wsparciu ojca chorego dziecka, nie należy doszukiwać się zasad, które dotyczą tylko i wyłącznie jego osoby. W zespole hospicyjnym stosuje się zasady postępowania zgodne z przyjętymi standardami tego rodzaju działań pomocowych. Wśród nich można wymienić zasadę konieczności akceptacji nieuchronności cierpienia ${ }^{36}$ i śmierci oraz leczenia, które ma charakter ściśle objawowy: „Nie wydłuża się ani nie skraca życia chorego"37, a także obowiązek informowania o postępach choroby. Wsparcie ojca wpisuje się więc w całokształt działań pomocowych świadczonym przez hospicjum.

Dla pełniejszego ukazania zakresu oddziaływania hospicyjnego warto przytoczyć definicję wsparcia społecznego. Pomimo braku spójności w definiowaniu tego pojęcia, można przyjąć, że jest ono wyjątkową relacją międzyludzką, poprzez którą jednostki udzielają sobie nawzajem rzeczywistej pomocy i tworzą sieć kontaktów interpersonalnych, które mogą być oparciem w chwilach potrzeby. Działania hospicjum zakładają dobrowolność osób udzielających pomocy, jak i wspieranych. Pomoc świadczona jest w sytuacjach trudnych, stresogennych itp. ${ }^{38}$ Wsparcie rozumiane w ujęciu funkcjonalnym można podzielić na: emocjonalne, informacyjne, instrumentalne, rzeczowe ${ }^{39}$ oraz duchowe ${ }^{40}$. Zaprezentowanie sposobów jego realizacji pozwoli na stworzenie szerszej perspektywy rozumienia opisywanego zjawiska.

\section{Praktyczna realizacja zasad wsparcia ojca chorego dziecka}

Trudno jest wskazać rodzaj wsparcia społecznego, które jest udzielane jako pierwsze. Jest to bowiem uzależnione od specyficznej sytuacji każdej rodziny. Można jednak przyjąć, że pierwsza z potrzeb rodziców to rzetelna wiedza dotycząca stanu zdrowia ich dziecka. Najczęściej jest to informacja trudna do przyjęcia, ale bez niej nie da się zorganizować życia dziecka, które zostaje wypisane ze szpitala i skierowane pod opiekę hospicyjną. Rodzice dziecka wracającego do domu winni posiadać precyzyjny opis choroby oraz wskazania co do dalszej opieki. Praktyka pokazuje jednak, że rodzice, jeśli nawet znają diagnozę, to nie zawsze są do końca świadomi jej znaczenia. Często trafiają do domu w stanie niepogodzenia. Aby jednak cokolwiek zmienić, muszą znać prawdę.

\footnotetext{
${ }^{36}$ Por. K. de Walden-Gałuszko, Założenia i podstawy ruchu hospicyjnego, [w:] Pielegniarstwo...,

${ }^{37}$ T. Buss, Choroba nowotworowa, [w:] Przewlekle chory..., s. 59.

${ }^{38}$ Por. M. Winiarski, Wsparcie spoleczne, [w:] Encyklopedia pedagogiczna XXI w., red. T. Pilch, t. 7, Warszawa 2008, s. 270-272.

${ }^{39}$ Por. B. Ziółkowska, Dziecko chore..., s. 173-174.

${ }^{40}$ Por. M. Winiarski, Wsparcie społeczne, s. 273.
} s. 19. 
Prawda o stanie dziecka jest dla ojca szczególnie trudna do przyjęcia, gdyż wywołuje pewien rodzaj żałoby, związany z niespełnionymi nadziejami związanymi z dzieckiem. Można przyjąć, że prawda przedstawiona przez lekarza hospicyjnego zgodnie z zasadami komunikacji ${ }^{41} \mathrm{i}$ wyczuciem sytuacji, nie spowoduje kolejnych frustracji, ale pomoże dobrze zorganizować każdy dzień życia dziecka. Dostępność personelu medycznego, który opiekując się dzieckiem na bieżąco służy rzetelną informacją, staje się wsparciem, które może wnieść w dom dziecka wiele pokoju. Może także pomóc ojcu starającemu się przeintelektualizować problem choroby w wypracowaniu korzystniejszej strategii adaptacji do choroby. Wsparcie będzie też przydatne ojcu, który nie otrzymując odpowiedzi na nurtujące go pytania, zaczyna szukać jej w internecie. Zdarza się bowiem, że buduje on obraz choroby, korzystając z portali, które zawierają wątpliwe informacje na temat choroby dziecka. Ważnymi pytaniami ojca są także te, które wybiegają w przyszłość i dotyczą śmierci dziecka. Wiedząc, kiedy może ona nastąpić, ojciec ma szansę na przeżycie tzw. żałoby antycypowanej, która opiera się na przeczuciu zbliżającej się śmierci:

Żałoba antycypowana jest zazwyczaj przejawem przyjmowania realności choroby i śmierci swojego bliskiego oraz tego, że śmierć bliskiego nie oznacza równocześnie śmierci własnej. Pytania: „Jak poradzę sobie bez niego? Jak będę żyć?" świadczą o wyobrażaniu sobie swego życia po śmierci kochanej osoby, są nieśmiałą próbą nadania mu jakiegoś sensu i wymiaru ${ }^{42}$.

W kontekście śmierci dziecka ważna jest również wymiana informacji, przeżyć i doznań pomiędzy rodzicami, którzy przeżyli śmierć swoich dzieci. Jedną z okazji do tego są spotkania grupy wsparcia, na którą są zapraszani rodzice przeżywający żałobę.

Funkcja informacyjna jest bardzo ściśle związana z wspomaganiem emocjonalnym. Możliwość stawiania pytań członkom zespołu hospicyjnego jest jedną z form „wentylowania uczuć”, tak potrzebnego rodzinie chorego dziecka. Stres przeżywany przez ojca może wywołać w nim uczucia, których się boi, gdyż nie zawsze są one zgodne z tym, jak w swoim przekonaniu powinien postrzegać chorobę swojego dziecka. Lęk może budzić w nim agresję skierowaną przeciwko pozostałym członkom rodziny bądź innym osobom, także tym, które świadczą pomoc. Chcąc przed tym uchronić ojca dziecka, zespół udziela wsparcia psychologicznego. W kontakcie z rodziną chorego dziecka psycholog musi zmierzyć się z odczuciami lęku i przygnębienia i starać się im zaradzić. Jego ważnym zadaniem jest doprowadzenie rodziców i rodzeństwa do zaakceptowania uczuć chorego i własnych ${ }^{43}$. Wyzwaniem dla psychologa jest również nauczenie rodziców dostrzegania potrzeb zdrowego rodzeństwa, które często jest zaniedbywane.

Bardzo delikatną sferą oddziaływań psychologicznych jest pomoc w umacnianiu więzi małżeńskich. Napięcia związane z chorobą dziecka mogą skłaniać do odejścia

${ }^{41}$ Por. K. de Walden-Gałuszko, Problemy psychiczne..., s. 210-215.

${ }^{42}$ P. Krakowiak, A. Paczkowska, E. Starkel, Praca socjalna ..., s. 27-28.

${ }^{43}$ Por. B. Kromolicka, Holistyczny charakter opieki nad przewlektymi i terminalnie chorymi, [w:] Przewlekle chory..., s. 264-265. 
z domu i ułożenia sobie życia poza przestrzenią cierpienia totalnego. Jak pokazuje praktyka hospicyjna, taka sytuacja jest dość częsta. Dlatego wsparcie emocjonalne winno wzmacniać więzi małżeńskie, pomagać w modyfikacji celów funkcjonowania rodziny i uczyć nowych sposobów komunikacji małżeńskiej. W ten sposób trudna sytuacja rodzinna może sprzyjać zbliżaniu się członków rodziny do siebie i umacnianiu wzajemnych więzi ${ }^{44}$.

Wsparcie instrumentalne polega między innymi na wdrażaniu rodziców w umiejętności potrzebne do odnalezienia się w nowej rzeczywistości. Ważną rolę spełniają pielęgniarki, które spędzając dużo czasu z chorym dzieckiem, dobrze znają jego potrzeby i mogą stać się dla rodziców oparciem w trudnych chwilach. Pomoc instrumentalna usprawnia opiekę nad dzieckiem i zmniejsza stres członków rodziny. Jest to szczególnie ważne w przypadku ojców, którzy dzięki rzetelnej instrukcji mogą sami podejmować czynności opiekuńczo-lecznicze. Mają dzięki temu okazję zbliżyć się do swojego dziecka, a jednocześnie dać mu się poznać poprzez zmysły, choćby przez dotyk. Posiadając odpowiednie umiejętności pedagogiczne, ojcowie mogą wychowywać chore dziecko i wprowadzać je w świat wartości na tyle, na ile pozwala jego stan zdrowia. Dzięki temu mogą odczuć satysfakcję, która dla każdego ojca jest bardzo istotna. W ten sposób ugruntowuje się relacja rodzica z dzieckiem.

W pracy hospicyjnej zdarzają się sytuacje, w których pomoc materialna jest pierwszą formą wsparcia udzielonego rodzinie. Dzieje się tak wówczas, gdy dziecko przed wypisaniem ze szpitala musi mieć zagwarantowany odpowiedni sprzęt medyczny, zapewniający właściwą opiekę po powrocie do domu. Dlatego pomoc rozpoczyna się od wyposażenia pokoju dziecka w wysoko wyspecjalizowany sprzęt medyczny, który zamienia pokój w salę szpitalną. Z biegiem czasu pomoc socjalna staje się dla wielu rodzin odciążeniem w ich troskach i zapewnieniem dalszego funkcjonowania, zwłaszcza gdy pracę zarobkową podejmuje tylko ojciec. Wsparcie socjalne może stanowić dla niego niełatwą do przyjęcia formę pomocy. Jednak jeśli jest ona udzielona w sposób profesjonalny, pozwala odbudować w rodzinie poczucie bezpieczeństwa.

Pomoc socjalna nie polega jedynie na przekazywaniu rodzinie żywności czy sprzętu medycznego. Przyjmuje ona także formę doradztwa w zakresie rozwiązywania kwestii prawnych czy socjalnych przez opiekunów dziecka ${ }^{45}$, dzięki czemu przeciwdziała ich bierności. Odpowiednie zmotywowanie ojca do zdobycia należnych rodzinie świadczeń może okazać się ważnym krokiem do jego zaktywizowania. Szczególną formą wsparcia może być obecność wolontariuszy, którzy zajmując się chorym dzieckiem bądź organizując czas zdrowemu rodzeństwu, umożliwiają rodzicom odpoczynek i wytchnienie. Także organizowane przez hospicjum spotkania dla rodzin chorych dzieci mogą stać się ważnym krokiem w kierunku ponownego zaangażowania się w życie towarzyskie. Nie sposób nie docenić roli spotkań

${ }^{44}$ Por. A. Maciarz, Psychoemocjonalne $i$ wychowawcze problemy dzieci przewlekle chorych, Kraków 2001, s. 40.

${ }^{45}$ Por. P. Krakowiak, A. Paczkowska, E. Starkel, Praca socjalna ..., s. 14. 
o charakterze sportowym ${ }^{46}$, w których ojcowie mogą nie tylko lepiej siebie poznać, ale również pozbyć się wielu trudnych emocji.

W działaniach pomocowych świadczonych przez zespół hospicyjny nie brak odniesienia do duchowej sfery życia ludzkiego. Pielęgnując ciało, lekarze i pielęgniarki troszczą się również o wewnętrzną kondycję pacjenta. Szczególną rolę pełni w tym względzie kapelan hospicjum. Kontakt z nim może być dużą pomocą w przygotowaniu rodziny na odchodzenie dziecka. Działania kapelana ukierunkowane są na głoszenie słowa Bożego i udzielanie sakramentów, zwłaszcza sakramentów inicjacji chrześcijańskiej oraz sakramentów związanych z chorobą i śmiercią ${ }^{47}$. Kapelan może udzielić wsparcia sakramentalnego zarówno choremu dziecku, jak i członkom jego rodziny. Poprzez wyjaśnienie treści poszczególnych sakramentów duszpasterz winien ukazać miłość, jaką dziecko i jego bliscy mogą przyjąć i przez to odczuć obecność Boga wśród nich. W ten sposób pojawia się w ich życiu nadzieja ${ }^{48}$, która jest ukierunkowana na rzeczywistość po śmierci i ma swoje źródło w obietnicy złożonej przez Boga, który przez Jezusa Chrystusa zapowiedział życie wieczne (J 14, 1-3).

Mając świadomość, że religijność mężczyzny różni się od sposobu przeżywania kontaktu z Bogiem przez kobietę, kapelan może motywować ojca dziecka do zaangażowania religijnego na miarę jego potrzeb. Pomoc w odzyskaniu wewnętrznego pokoju jest bowiem bardzo ważnym elementem wsparcia cierpiącego ojca.

Każdemu ojcu społeczeństwo stawia wysokie wymagania. Fakt, że coraz częściej mówi się o kryzysie ojcostwa, świadczy o tym, że ojcowie coraz rzadziej w pełni realizują swoje zadania. Należy jednak pamiętać, że dobrzy ojcowie potrzebni są w każdej rodzinie, a szczególnie w takiej, w której pojawia się choroba dziecka. Roli ojca nie jest w stanie wypełnić matka ani ktokolwiek z domowników czy osób z zewnątrz, dlatego wzrasta znaczenie instytucji, które chcą wspierać ojców w pełnieniu przez nich obowiązków rodzicielskich.

Działalność hospicjum domowego dla dzieci obejmuje pomoc choremu dziecku i jego rodzinie. Zespół hospicyjny chce w warunkach skrajnych napięć wewnątrzrodzinnych pomagać wszystkim, którzy otwierają się na wsparcie z zewnątrz. Pomoc hospicyjną przedstawiono w kontekście roli ojca w rodzinie $\mathrm{z}$ terminalnie chorym dzieckiem. Wsparcie, które może on otrzymać, ma na celu pomoc w przezwyciężaniu trudności związanych z chorobą dziecka. Świat wewnętrznych przeżyć mężczyzny stanowi tajemnicę. Istnieje pewne ryzyko, że działania pomocowe naruszą sferę intymności mężczyzny bądź też okażą się niezgodne z oczekiwaniami ojca. Jednak

${ }^{46}$ Por. Sportowe środy z Alma spei, www.almaspei.pl (2.02.2012)

${ }^{47}$ Por. L. Szczepaniak, Troska o dziecko umierajace w szpitalu. Studium z pogranicza medycyny i teologii moralnej, Kraków 2008, s. 144-155.

${ }^{48}$ Por. B. Kromolicka, Holistyczny charakter opieki..., s. 265-266. 
pomimo tego ryzyka zespoły hospicyjne podejmują działania dające nadzieję na poprawę sytuacji. Opierają je na przekonaniu, że rodzice, którym okazuje się odpowiednie wsparcie, zadbają o swoje dziecko lepiej niż najbardziej skuteczny zespół hospicyjny. Jeśli jednak będzie trzeba, to członkowie hospicjum pomogą rodzinie przygotować się do odejścia dziecka, by miesiące żałoby nie naruszyły w znacznym stopniu jej struktury.

Główną przeszkodą, którą musi pokonać rodzina chorego dziecka, jest stres. Niestety, nikt nie jest w stanie go całkowicie wyeliminować. Jednak dobro, jakim może zostać obdarowana rodzina dziecka, może spowodować, że nie będzie się ona czuła bezradna. Członkowie hospicjum zawsze mogą pomóc, choćby poprzez obecność przy łóżku dziecka i jego rodzinie. Wszystkie działania podejmuje się w tym celu, by zgromadzić przy dziecku całą rodzinę, a więc także jego ojca.

Dla pełnego zobrazowania poruszonych problemów wydaje się konieczne wszczęcie badań empirycznych. Ich wyniki umożliwiłyby uzyskanie informacji od samych ojców na temat pomocy, z której korzystają. To pozwoliłoby na zweryfikowanie poziomu adekwatności działań podejmowanych przez pracowników hospicjum, a jednocześnie wskazałoby drogi dalszego rozwoju działań pomocowych.

\section{Summary}

\section{The role of the father in hospice support offered to a terminally ill child and its family}

A child's terminal illness makes it very difficult for the father to fulfil family functions. Hospice support provided by a multidisciplinary team aims at overcoming these difficulties. The mission of a hospice is to care for both the ill child and its family. The support offered to the father of the ill child is specific and adequate to the father's social role. It embraces the basic spheres of the father's activity in the family and is oriented to his needs.

\section{Keywords}

Father, hospice care, stress, support, terminal illness 
